\section{SI-1 韭A非B韭C型肝炎の赛態}

国立長崎中央病院 臨床研究部 $\bigcirc$ 八楧弘、古賀满明 矢野右人

【目的】本邦における非A非B非C型肝炎の実態を明か にする為、抗体診断のみならず遗伝子診断を併用して 明確に診断を行い、非A非B非C型肝炎、G肝炎の頻度 とその臨床像について険討した。

【対象、方法】対象は、1976年から1995年の期間、国 立病院急性肝炎共同研究班（179国立病院から構成さ れる）に登録された散発性急性肝炎3048例と、1990年 から 1994年の期間当科に入院した慢性肝炎718名、肝 硬変218名、肝癌237名である。起因ウイルスの同定で、 抗体診断はIgMHA,HBsAg,IgMHBc,HCVAb,HEV-Abを 用いた。遗伝子診断では、HBVの検出は血清から全 DNAを抽出後、HBV-DNAのPCR反応をおこなった。 HAV,HCV,HDV,HEV,HGVの検出は、血清より全RNA 抽出後、 random primerでT反応を行い、各種ウイルス ゲノムに特異的primerを用いてPCR反応をおこなった。 なおHGV-RNAのprimerは、HGV-NS3領域と5'noncoding領域を用い、 nestedPCRで検出した。

【結果】散発性急性肝炎3048例中、抗体猃断でA型 $1285(42 \%) 、 B$ 型792(26\%)、C型 $275(9 \%) 、$ 非A-C型 696(23\%)の頻度であった。非A-C型696例中E型は2例で あった。非A-C型の肝障害の程度は、平均値 $(\mathrm{n}=152) て ゙$ GOT693IU/ML、GPT883IU/ML、T.B4.2mg/ml とA,B,C 型の平均值と此較していずれも低值であり、臨床型は

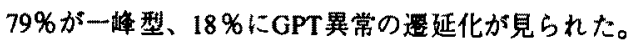
抗体診断で非A-E型散発性急性肝炎と診断した22例て 全ウイルスゲノムの検出をおこない、うち1例で HBV-DNA、2例でHGV-RNAが検出された。1990年以 後非A-E型散発性急性肝炎と衫断した90例でのHGV. RNAの検出はNS3 領域primerで4例(4.4\%)、5'non-coding 領域primerて7例(7.8\%)検出された。G型急性肝炎の肝 障害の程度は轻く、一過性感染例と、持続感染化し GPT持続正常のキャリアー移行例が認められた。 対象例中、既知の原因を除いた非BC型慢性肝疾患は、 慢性肝炎9例、肝硬変5例、肝洆9例で、うち慢性肝炎1 例において5' non-coding 領域primer でHG V-RNAが検出 され、その列での肝㜔害の程度及び組織変化は軽微で あった。

【考察、結諭】非A-C型散発性急性肝炎の頻度は $23 \%$ でり、うちE型の関与は極めてまれで、G型は約10 \%の出現頻度てあった。韭A-C型散発性急性肝炎の多 くは、既知の肝炎ウイルスとは異なると考えられた。 非A-C型散発性急性肝炎の踟床的特徽は、朋障害の程 度は軽く透延化例でも予後は一般に良好であった。非 $\mathrm{BC}$ 型慢性肝疾惠におけるG型肝炎の頻度は低く、病期 の進展例では見られないことから、非BC型慢性肝疾 患におけるHGVの寄与は少ないと考えられた。

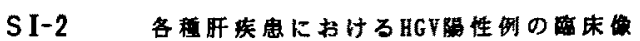

大匞市立大学第三内科

○西口篮平、埴見進、埋木䤃夫

【目的】1995年、Genelabおよび よってほほ同時に新しい数ウイルス(HGV)が発見され た。HGVはキャリアー事が咀VやHCVに匹敕するといわれ、

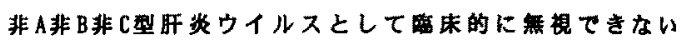

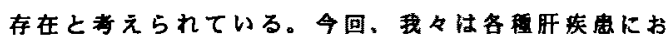
けるHGVの性革をRT-PCR法にて梌索し、HGV感架者の

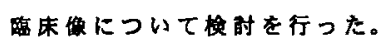

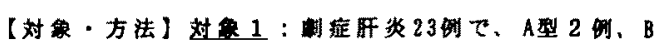

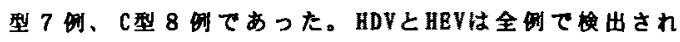

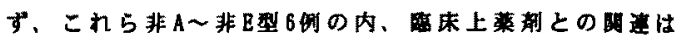

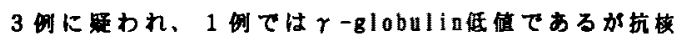

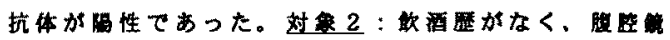

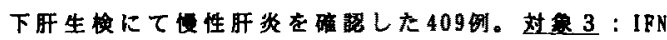

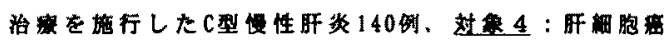

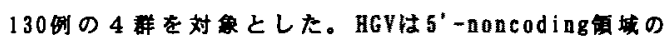
primert用い、nested RT-PCR法にて定した。

【成綎】(1)症肝炎23例中、HGVは初期血消か5は全

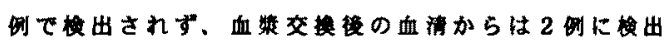
された。血策によりHGV感染が生じた 2 例中 1 例柱生存

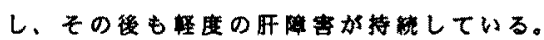

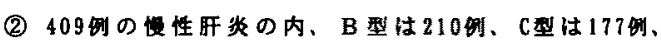

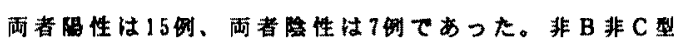

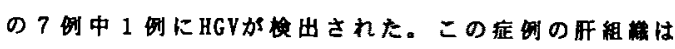

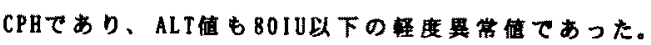

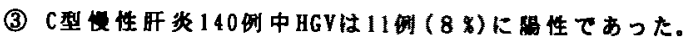
C型単独とC型G型合并群とは血㠊、HCV genotype、A LI、アルプミン值、血小板数、HAI scoreに差を淁めな 加った。IFN投与によって、HCVは39/140约 (28x)、HGV

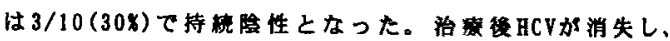

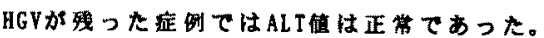

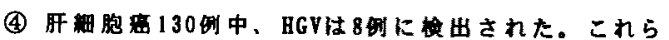
8到の内、2甽は日Bs抗原加性、1 あり、他の5侧はHCV RNAが路でった。

【孝实】(1)HGVは血によって感架し、或架が持繶す る症洌も存在した。急性期の所度害の程度が埕度であ

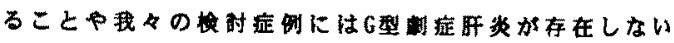
ことから、G型急性所炎の症化率は佂いと孝えられた。

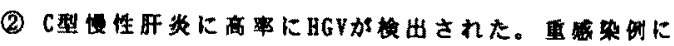
おいてHGVが肝害の進展速度を早力た可能性は否定で

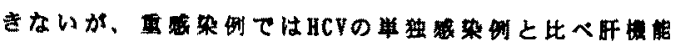

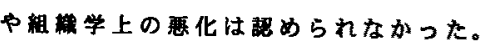

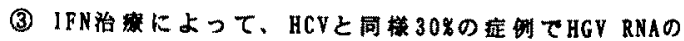
完全消失が琶められた。

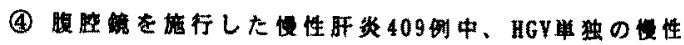

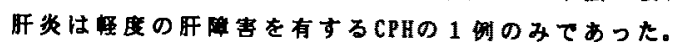

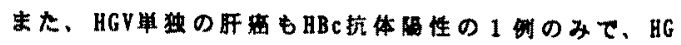

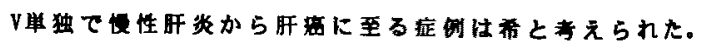


SI-3 非A 非 B 非 C 型肝炎の頻度と実墛

要授大学第 3 内科

○道堯浩二郎 堀池典生 恩地森一

【目的】非A 非 B 非 C 型肝炎の頻度と実態を明

らかにすることを目的とした。

【方法】1990年から1995年に当科に入院した

急性、慢性肝疾虫計747列を対象とし、その成

因別頻度と監床像を检討した。成因検索として、

急性肝资 $(A H)$ 、剂应旰资 (FH) のスクリー ニングには|gM-ant|-HA, IgM-anti-HBc， HBs Ag， HCV-RNA、惿性肝炎 $(\mathrm{CH})$ 、肝硬变 (LC)、肝細胞疗 (HCC) のスクリーニンクに はHBsAg，ant $\mathrm{i}-\mathrm{HBc}$, ant $\mathrm{i}-\mathrm{HCV}$ を施行した。 上記陰性例を含む一部の症列でant 1 - HEV 上 PCR法によるB、C、G ( GBV-C) 型肝炎ウイ ルスの道伝子を検討した。HGVのPCRは5 UTR領域とNS3 領域で施行した。

【成精】上記スクリーニング検㭗でA，B，C型 肝炎ウイルスマーカーが陰性の症例は、他の原 因が明らかな列を除くと、AH $9 / 82$ 例、FH $9 / 16$ 例、 $\mathrm{CH} 3 / 309$ 列、LC $5 / 155$ 例、 HCC $10 / 185$ 例、計 $36 / 747$ 例 $(4.8 \%)$ であった。AH、FHのうちHBV抗原抗体陰性で HBV - DNA 煬性列を1别づつ㒛的、またCHのう ち HCV抗体险性でHCV - RNA 隄性例を1例証め た。これらの例を除くと、非A非B非C型肝资の 頻度は、AH $10 \%$, FH $50 \%, \mathrm{CH} 1 \%$, LC $3 \%$, HCC $5 \%$ あった。anti-HEVは25例で検索し、 全例隆性。HGVは81列で挨索し、HBV、HCV との重感染例を3例（FH 2例、CH 1例）に認め たか、非A 非B非C型肝炎2 7 列では全例隆性であ った。非A非B非C型AH例には输血後肝炎例はな く、重症肝炎列を1列、また高度の脾腫や白血 球の減少を伴う列などを認め，原因の多倳性が 推定された。組樴学的には、2例でbridging necrosisを铝め、他の6 例では肝炎像が比较的 轻砤であった。CHの2列では、組㙌学的に炎症 細泡の浸润がB型、C型に比へてて轻敎で、うち 1 例はインターフェロンが有效であった。LC例で は、HBV性、HCV性と比较して踟床像に特に差 異を認めなかった。肝粨胞症列のうち2例は高

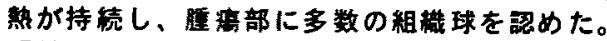

【結語】(1スクリーニング娭查でA、B、C型肝 炎ウイルスマーカー磨性症例を747 例中36例 (4.8\%) に琶めた。(2)これら36例中HBV DNAを2 例 $(6 \%)$ 、HCV - RNAを 1 例 (3\%) に認めたか、HGV - RNAは䜀めなかった。以上 より、いわゆる非A非B非C型肝炎のうち、一部 はHBV、HCV性を原因とするが、HGV性は低頻 度と考えられ、他の大部分の症例は既知の肝炎 ウイルス以外の原因によることが推定された。
SI-4 5'UTR、NS3、NS5 プライマーを用いた PCR 法およびLong distance RT-PCR 法による各種肝 疾患における G 型肝炎ウイルス感染の检棓 金沢大学第一内科

○下田 敦、金子周一、小林健一

【目的】最近新しい肝炎ウイルスとして G 型肝炎ウイル ス(HGV)が報告された(Science 271:505,1996)ので、急 性肝炎例、劇症肝炎例、慢性肝炎例、肝硬変例、肝㿋例 について、HGV 感染の有無を5UTR、NS3、NS5 プラ イマーを用いた PCR 法および long distance RT-PCR 法を用いて検討した。

【方法】患者血清 $200 \mu 1$ をダアニジンイソチオシアネ 一ト緩衝液処理後、ウイルス RNA 回収し直ちにラン ダムプライマーおよび逆転写醭素(RT)で cDNA を作成 Lた。HGV の 5'側非媩訳領域(UTR)、非構造領域(NS)3 およびNS5 で 型肝炎ウイルスと相補性のない部分を 選び PCR プライマーとした。5UTR、NS3、NS5 領域 でそれぞれ PCR スクリーニンクを行い陽性検体を選択 後、5UTR-NS3 間で long distance RT-PCR を行った。 Long distance PCR 反応時間は $94^{\circ} \mathrm{C} 40$ 秒、60 ${ }^{\circ} \mathrm{C} 1$ 分、 $68^{\circ} \mathrm{C} 7$ 分で 35 回反応した。PCR 反店物を $1 \%$ アガロー スゲルで電気泳動し、4706 bp(44nt-4750nt)バンド検出 例を陽性とした。陽性バンドは抽出後 DNA シーケンサ にて直接塩基配列を決定した。

【成績】5UTR、NS3 プライマーを用いることにより腎 疾患患者の急性肝炎例および肝硬変例に特異的陽性バン ドを認めた。3 例の㓺症肝炎例および病理組蟣学的に慢 性肝炎と診断しえた 5 例では陽性バンドを認めなかった。 NS5 プライマーを用いることにより HBs 抗原陰性肝瘦 61 例中 7 例が陽性となった。この7例は全例輸血歴を 認めかつ HCV 抗体陽性であった。輸血歴を認めない肝 癌 15 例はHCV 抗体の有無に関保なくHGV 陰性であっ た。Long distance RT-PCR 法を用いることにより、腎 疾患患者の急性肝炎例おうび肝硬変例に約 $5 \mathrm{~kb}$ の特異 的陽性バンドを認めた。塩基配列を決定しえた 5UTR、 NS3 領域の相同性は Science 報告例に対してそれぞれ $93 \% 、 81 \%$ あった。急性肝炎例、肝硬変例間では大き な塩基配列の違いを認めなかった。檴造領域に関しては サフクローニング後各クローンについて塩基配列決定中 である。

【結論】輸血歴がありかつ HCV 抗体陽性である肝癌に HGV 重複感染が多く磟められだ。 HGV 重複感染が肝 癌の進展に関与しているのか否か、またどの領域のプラ イマーが診断に優れているのかは検討中である。Long distance RT.PCR 法により、5UTR が NS3 領域まで を連続して検出することは、5UTR、NS3、NS5 領域単 独検出法に比べて感染クローンの検討に迫るものと思わ れた。今後検討症例数を增やすとともに、各クローンよ り塭基配列を決定し詳細に険討することが必要と思われ た。 
37巻 suppl. (3) (1996)

SI-5 非B韭C型肝疾患におけるH V V感染につ いて - 自己鬼疫性肝㷋就診例との比較を含め一 大䛀大学第一内科

○三薜治、尾下正秀、林 紀夫

【目的】 G型肝炎ウイルス（以下、HG V) が発見さ れ、非 B 非C型肝桨の一部にH G V感染が関与してい ることが報告されている。しかし診断方法に関しては 抗体アッセイ系が確立しておらず、RT－PCR法に よって血中のHGV-RNAを証明している。しかし RT-PCR 法では偽陰性症例の存在も否定できない。 そこで3つの独立したRTーPCR法にて非B非C型 旰炎患者の血中 H GV-RNAの同定を試み、その意 義を检討した。また自己免疫性肝炎疑診例における血 中 HGV-RNAも検討した。

【㘯法]対解は非B非C型肝疾患と診断された75例で、 内訳は急性肝炎 8例、慢性肝炎 41例、肝硬変 11 例、 鬥琶 15例である。Linnenらの方法にしたがいNS5 領 城に設定したプライマー(方法 I、77F/211R；方法 II、 4512MF／4657MR）を用い、RTーPCRを施行した後 オリゴプロープを用いサザン法にて解析した。また、 与芝らの方法に従いNS3 領域に設定したブライマー によるRTーnested PCR法（方法 III）でも検討 した。さらに面中HGVーR NA陽性症例に㧍いて、 方法Iおよび III で增幅された産物をクローニングし 壏基配列を法定した後、既報の HGVクローンとの相 同性を比较検討した。

【結果】(1) 非B韭 C型旰突患 75例中 7例 (9.3\%) に Ifn中 H G V-R N A を諗めた。（急性肝炎 1/8、12.5\%； 慢性肝炎 4/41、9.8\%; 肝䂠変 $1 / 11 、 9.1 \%$; 肝癌 $1 / 15$ 、 6.7\%) H G V-RNA陽性 7例はすべて方法 I および II で証明可能であったが、万法 III では内 1例が陰性 であった。(2)H GVーR NA陽性症例のクローンは既 報のクローンとNS5領域（方法I）においては核酸レ ベルで94.4-97.2\%、アミノ酸レベルで91.4-97.1\% の相同性を有していだ。一方、NS3領域（方法 III） ではアミノ酸レベルで93.9-97.0\%の相同性を認める ものの核酸レベルでは82.8-91.8\%にとどまっていた。

(3) 自己免疫性肝炎疑診例峙全例血中HGV-RNAが 险性であった。可いずれの方法でもHGVーRNAが 除性の非B非C型慢性肝焱症例で、旰生検が施行され ていたものを榆討するとウイルス性肝炎の組織像を呈 していた

【結諭】非B韭C 型肝资の䄪10\%にH GV 感染が認め られ、G型肝炎の可能性が示陵された。H G V 感染の 同定方法は、伪陰性症例を考虑すると椱数のプライマー を用いたRTーPCR法を併用し診断する必要があると 考えられた。複数の方法によるHGV-RNAの検討 でも G 型朋炎が否定的な非 B 非C型の急性肝炎および 慢性肝炎が存在し、その組織像より末知の奸炎ウイル スの存在が考えられた。

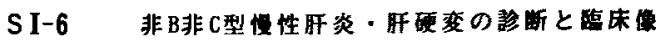
奈良翼立医科大学第三内科

○植村正人、石井襀的、端井田

【目的】殿近、A型B型C型肝炎以外の肝炎の存在加注目 されている。今回、我々は、B型およひ型数炎ウイル

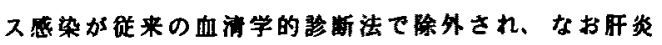
ウイルス起因と考えられた性周筷を透伝子工学的

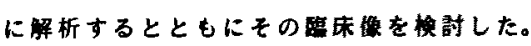

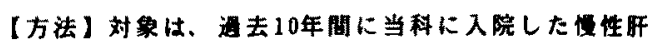

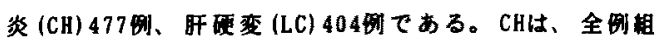
織学的にヨーロッバ分類を用いて影断し、LCは画瀂所 見を含め合的に診断した。HBV-DNA，HCV-RNAを含む 血清マーカーが阵で非B非C型肝炎と診断した症㤡に

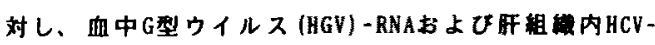
RNAの检出を式みた。HGVは、ベーリンク社紫キットを 用い、肝組内HCV-RNAは、バラフィン包埋組㩆をつ ノールクロロホルム法によりRNAを抽出し、既報(久富 5、肝素9:511，1995)の如くRT-PCR法により案した。 【結果】CHのうちわけは、C型304明 (63.7x)、B型158明 (33.1x)、B+C型9例 (1.9x)、非㫵C型6峢 $(1.3 x)$ であっ

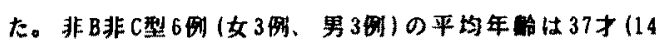

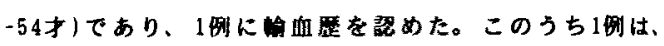
VCA-IgG 1280倍、VCA-IgM 20倍、EBNAは䧔性であり、 Southernblot hybridizationにて末梢血りンバ球およ び目道有核湅胞から大国のEbstein-Barr (EB)ウイルス ゲノムが惨出され、传性EBウイルス感染症と診断した。

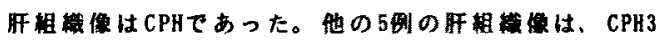

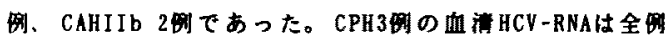

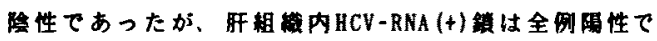

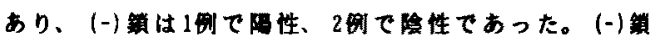
が性の1时では、生橹後8年間トランスアミナーセの

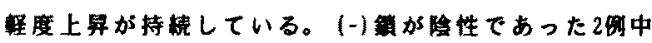

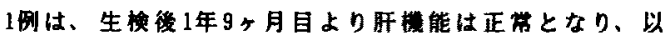

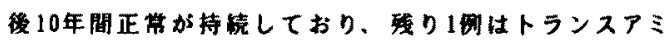

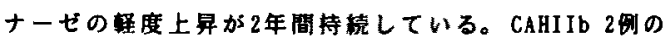

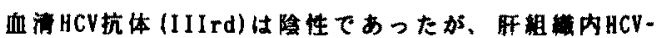

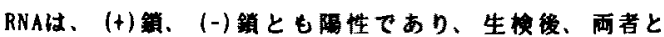

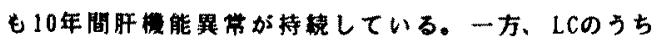
わけは、C型277明 (68.6x)、B型105明 (26.0X)、B+C型 19 例 (4.7\%)、非B非C型 3 间 $(0.7 x)$ でった。非B非C㤠 3

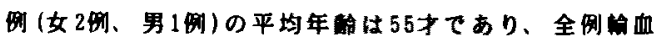

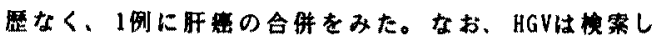

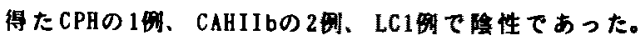

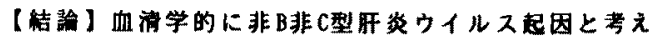

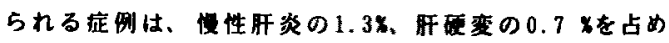

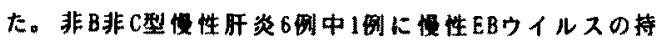

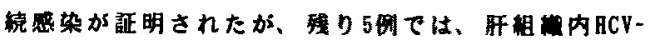

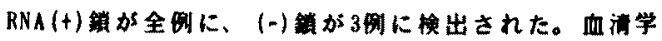

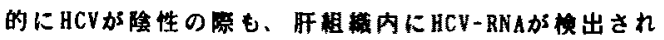

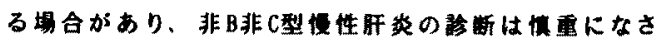
れるぺをと考える。 
SI-7 非 B 非 C 型慢性肝疾患、供血者、血液疾患に おける GBV-C/HGV感染とgenotypeお 上び臨床的意義 ○鈴木繁、清上雅史11

名古屋市立守山市民病院内科、1)名古屋市大第二内科 【目的】本年になりヒトを宿主とする非 A - E 型肝炎 ウイルスとしてGB Virus C $と$ G 型肝炎ウイルス (HGV) が報告された。今回我々は名古屋地区における慢性肝

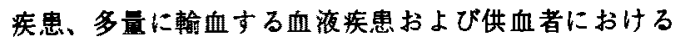
GBV-C/HGVの感染状況摆べ、一部の症例で塩基配 列の決定をおこない分子進化学的なgenotype分類を行 い、日本または当地区特翼的な genotypeについて検討 した。【対象と方法】名古屋地区に住む203例の慢性 肝疾患、34例の血液突患、日赤より供給された供血者 200例の計 437例である。慢性肝疾患の内訳は、HCV 抗体陽性者 144 例、HBs抗原陽性者 31例、HCV抗体と HBs 抗原西者とも陽性 2 例、西者とも陰性 (非 B非 C) 26例である。血液疾患は内訳は悪性疾患24例、非悪 性患10例である。HBs抗原陽性者は認めず、HCV 抗体陽性者は 3例であった。 GBV-C/HGVRNA(GRNA)の検出は， $5^{\prime}$ 非翻訳領域の塩基配列を使用した特 異的primerによるRT-PCR法で扔こなった。Ｇ-RNA陽 性例の一部は塩基配列決定し、世界中18ケ国より集 め同様に塩基配列を決定した120配列を対象として genotype分類を試みた。【成續】(I) 慢性肝疾患 203 例中 10 例 (4.7\%)がG-RNA陽性で、この10例中 1 例が HBs 抗原陽性，9够がHCV抗体陽性であった。非B非 Cの26例加ら法G-RNAは検出已れなかった。(II)供血 者 200例中 1 例 $(0.5 \%) か ゙$ G-RNA陽性であった。(III) 血液疾㭧患者 34 列中 5 例 (14.7\%)がG-RNA陽性であ った。黑性疾患24例中 4 例 $(16.7 \%)$ ，非墨性疾患10例中 1 例(10\%)が陽性であったが、これら陽性例は総輸血 量が多かった。さらにこれらG-RNA陽性 5 例中 2 例 (40\%)はHCV抗体陽性であった。また特発性血小板隇 少症 (ITP) 6 例中 1 列(16.7\%)がG-RNA陽性であった が、この陽性例の肝機能成嚗に特異的な所見はなかっ た。(IV) G-RNA陽性10例の塩基配列を決定し、世界 中の他の㙁基配列と分子進化学的分類をしたところ、 3 つのgenotypeに分類出来た。一つはGBV-Cに近縁な typeで、塩基配列を決定した10例中認めず、もう一つ はアメリカから報告されているHGVに近縁なtypeで、 10 例中 2 例 $(20 \%)$ 、さらにまだ報告されていないtype て、塩基配列老決定した10峢中 8 例(80\%)て、当地区 ではこのtypeがmajorと思われたが、而者間に臨床的 な差異は認めなかった。【結論】慢性肝疾患の $4.7 \%$ にGBV-C/HGV感染がみられたがHCVとの混合感染が 主で、単独感染は認められなかった。血液疾患患者の 14.7\%でGBV-C/HGV感染がみられたが、輸血との関 連が考えられた。さらに、GBV-C/HGVは3つに分け られ、新しいtypeが当地区においてはmajorと思われ たか臨床的には差を認めなかった。
SI-8HBs抗原陰性・HCVRNA陰性ALT異常供血 者血獎中のウイルス梾粒子

三重大学保健管理センタ-1, 同第 3内科 2

○渡辺省三 1 , 垣内雅彦 2 、生駒次朗 ${ }^{2}$

[目的] 最近，血液伝播性の非B非C型肝炎の候㭪病 原ウイルスとして、GBV-CとHGVのウイルスゲノム が分跳，同定された。禹者は，その塩基配列の相同性 から同一のものであることが明らかにされたが、ウイ ルスそのものの形態は不明のままである。そこで我々 は，HBs抗原陰性・HCVRNA陰性のALT異常供血者血 整中のウイルス様粒子の可視化を試み，その存在と GBV-Cウイルス㥜伝子の有無との関係について検討 を行った。

[方法] HBs抗原陰性・HCVRNA陰性のALT異常供 血者血洯13検体と正常コントロール血脽10検体を検 討対象とした．超遠心法にて1,000倍に銥樎した梌体 を20〜60\%革続ショ糖密度勾配溶液上に重屏し。 $100,000 \mathrm{~g} て ゙ 16$ 時間遠心後, ショ糖密度勾配分画を分 取した．各分画をさらにPBSで希釈して，超遠心法に て1,000倍に潧縮した電湿観察用試料を作製した.こ の分画試料をつォルンバール膜にのせ、ネガティブ染 色を施して、要顕下にウイルス様粒子の有無を観察し た. 血㩯体中のGBV-CRNAの検出は, NS3/helicase領域のブライマーを用いたnested PCR法(岡本) にて行った.

[成績] ウイルス様粒子は，HBs抗原陰性·HCVRNA 陰性のALT異常供血者血獎 13 検体中12梌体(92.3\%) と

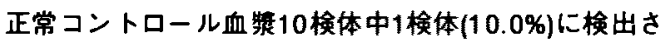
れ、それは比重1.14〜 $1.18 \mathrm{~g} / \mathrm{m} /$ 分画試料中に観察 された。可視化できたウイルス様粒子の形態には多形 性が詔められたが、多くのものは表面に9 12nmのス パイク様突起を有する直径50 80nmの球形粒子であ った.ウイルス様粒子を多数含む検体では、このもの と同様のスパイク様突起を有する直径100nm以上の球 形粒子と捍状の粒子も観察された。しかし、これらの ウイルス様粒子を含有する血洯模体中にはGBV-C RNAの検出されるものはなかった。

[結論] HBs抗原陰性・HCVRNA隆性のALT異常供 血者血嶈中には高事に多形性のウイルス様粒子が存在 した.そして、このウイルス様粒子の存在はALT值が 異常であることとの間に有意な( $\mathrm{p}<0.001)$ 相関を認め たが、それはGBV-Cなどの既知のヒト肝炎ウイルス とは異なるものであることが明らかとなった。 


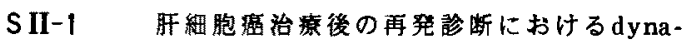
mic CTおよびdynamic MRIの有用性についての検期 大阪大学第一内科

○大前篤、片山和宏、林紀夫

【目的】近年、画像䥻断の進歩により肝細胞癌 ( HCC) の早期発見が可能となりかつPEITなどの治療法によ り生命予後の向上がみられている。しかし、他の悪性

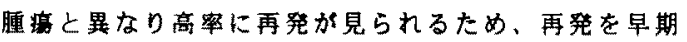
に、かつ正確に診断することにより、再治療を適切に 行うことが治境效果を上げるために重要な課題となっ てきている細な血流変化をとらえることのできるC TやMRIのdynamic studyはHCCの早期診断や治㙩勃 果判定に有用であることが指摘されてきているが、治 㿑後の再発診断における有用性については末だ检村さ れていない。今回、我々はHCCのTAE、PEITによる治 㫫例において dynamic CTおよびdynamic MRIを施行 し、HCCの再発診断における有用性を検討した。

【対象と方法】1995年1月より1996年6月までに、TAE を施行した112例のHCC症例中（可能なものにはPEIT を併用)、治終了1力月後にdynamic CTあるいは dynamic MRIにてHCC根治と診断された 35例を対象 とした。治虔後3カ月ことにdynamic CTおよびdynamic MRIを施行しそのいずれかで早期湌染もしくは、 後期相にて低染となった症例を再発と衫断し、血管造 影（DSA）および経動眽性門脈造影CT (CTAP) さら

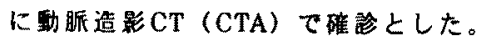

【結果】DSA、CTAP、CTAにてHCCの再発と診断され た症例は14例22病变でった。同所再発は10例10病変 (45\%)、異所性再哞は8例12病変 $(55 \%)$ であった。 dynamic CTでは8列12病落(同所再発は7病桨、異所 性再発は5病変)を模出し、sensitivityは $55 \%$ 、

positive predict valueは $92 \%$ あっった。dynamic MR Iでは13例16病変（同所再発は9病変、異所性再発は7 病変)が梌出され、sensitivityは73\%、positive predict valueは $80 \%$ であ、MRIは検出率は高いがfalse

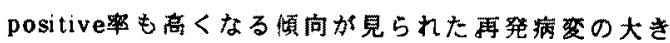
さは1 3cmで、平均 $1.3 \mathrm{~cm}$ であた。超音波検查での検 出は翼所性再発て6病㠇(60\%)であったが、同所再発 では 10 病変 $(90 \%)$ 梌出されたが画像上の変化がそし

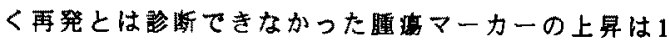
例（PIVKAーI）䛑めたのみであった。

【結論】dynamic CT およびdynamic MRIは、超音波 揄查や腫䮠マーカーに比し、TAEやPEIT後の HCC非 切除症例での再発部断に有用であると考えられた。

\section{S II-2 肝細胞萿再発後治療における肝切除の意義} 大阪府立成人病センター外科

○中野博史、佐々木洋、今闺真楼

【目的】肝細胞癌は根治切除後も再発军が高く、遠 陑成結向上の為には、再発例に祄する道切な治療が不 可欠である。我々は今まで、肝内再発例に对して皘極 的な再切除を施行してきたが、その意数について梌討 した。【新象】1980年-95年の肝細胞虎根治切除475 例中、288例に再発を認め、そのうち257例（89\%） が肝内のみの再発であった。257例中234例（91\%） に肝局所治療を施行した。Vp3例を除き、再肝根治切 除（O群）37例、肝動脈塞栓㬌法（T群）169例、工夕 ノール局注㞠法（P群）21例を对象としだ。【結果】 (1) 3治虔法の比輅。1) 再発後生存事の比較。再発 後の3、5年生存率は、O群で89\%、75\%、T群で45\%、 10\%、P群で74\%、19\%であった(Ovs P、OvsT:P

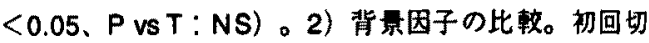
除時のICGR15は、O群で16士9\%、T群では21士10\%、

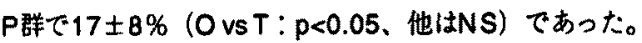
再発腫場個数は、単発/2-3個/4 個以上が、O群で28 /9/0、T群で46/45/78、P群で9/11/1であった (O、P vs T : p < 0.05、O vs P : NS) 。初回無再発期 間は、1年末满/1年以上3年末满/3年以上が、群で 5/17/15、T群で53/90/26、P群で7/10/4であっ た（Ovs T: p<0.05、他はNS）。3）良好肝機能、少 数再発における3治療法の比㜞。ICGR15<20\%で再発 腫痽了個以下の症例を3群加潠択し、再発後生存率を 比㜞した。再発後3、5年生存事は、O群 $(n=25)$ で83 $\% 、 74 \% 、 T$ 群 $(n=42)$ て51\%、14\%、P群 ( $n=12)$ て76\%、38\%であった（Ovs T : p<0.05、他はNS)。 〈2〉再肝根治切除例における検討。1）背景因子。

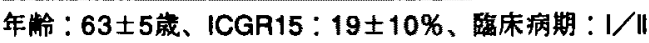

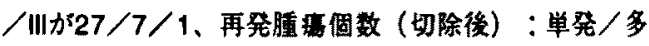
発が24/13、再切除時のStage：(I/II/III) が10/ 18/8であった。2) 再切除後無再発生存审 (2ndDFS)。 37 例全例の再切除後2、3年2ndDFSは68\%、34\%であっ た。3）背景因子別2ndDFSの比较。肝機能、腫㻛進行 度、初回無再発期間別に比較した。2、3年の2ndDFS は、ICG R15良好群（ฏ15\%）（n=14）で、65\%、 $49 \%$ 、不良群 (>15\%) (n=21) で69\%、43\%であっ た（NS）。再切除時肉眼的進行度のStage I $(n=10)$ で88\%、58\%、Stage II or III $(n=26)$ で58\%、19\% であった（p<0.05）。初回無再発期間3年末満群（ $n=$ 22）で79\%、26\%、3年以上群 (n=15) で62\%、34 \%であった（NS）。【桔後】1) 肝細胞虎切除後の残

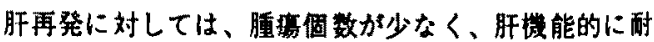
術可能であれば、再切除することが良好な予後につな がることが示惨された。。2）再切除のなかでい、再 発時の腫凊進行度がStage である因子が、再切除後の 長期無再発生存に案与することが示唆された。 
S II-3 肝細胞嵒 5 年简無再発例における背景因子

の検討

爱媛大学第三内科

O井内英人、堀池典生

目的)肝細胞蛅の同所再発は、治瘄法の向上により娍 少しているが、異所再発に関しては、未だ予防法はな い。今回、5 年䦔以上経過钼祭しえた肝細胞癌症例に おいて無再発例の背景因子について梌討した。方法)

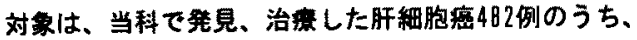
5 年間以上生存し、経墖を钼察しえた無再発例と異所

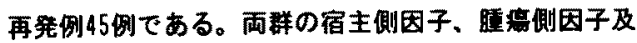
ひ治接法について、Wilcoxon模定及び多重ロジスティ ック解析を行なった。経遇中のGOT(IU/mI)の推移を I 群:50未淽、I 群:50以上100未満、正群:100以上の3群 に分けた。成程)镍再発群は17㤡(38\%)、異所再発群は 28例 (62\%) であった。無再発群の内訳は、男性13例、

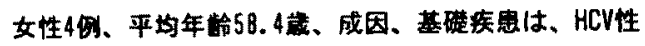
肝硬変14例、HBV性肝硬変了例、HCV性肝硬变における HCV-RNA量は、0.5Meq/mI以上 (DNAプローブ法)が9例中

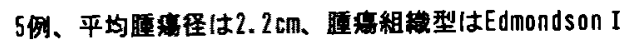
型9例、I 型8例であり，異所再吐群との有意差は認め

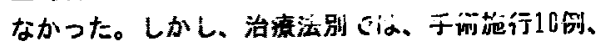
PEIT雄行5例、TAE施行2测であり、異所再発群に比し、 有意に $(P<0.05)$ 手街例を多く認めた。また再発率は、 I 群が四群、四群に比し、有意に $(P<0.05)$ 低く認めた。 多重ロジスティック析(性、年秢、K-ICG、血小板数、

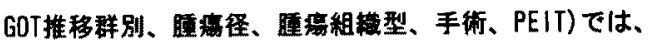
GOT推移群別のF值が2.121と、他に比し高い㑯向を示 したが有意ではなかった。宿主側因子のみ(性、年齢、 K-ICG、血小板数、GOT推移群別)の検討では、GOT推移

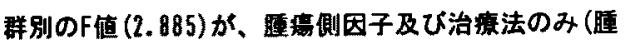

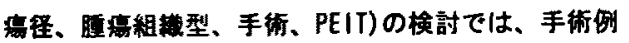
のF值 (2.815)が他の因子に比し、それぞれ高い傾向を 示したか、、共に有意差は認めなかった。結論)旰細胞 害症侧における無再吐例の背量因子として、GOTが 50IU/m|未满で推移することと、手街を拖行したこと が挙げられたが、多重ロジスティック解析では、共に 有意差は認めず、旰細胞盘の多中心性発生あるいは肝 内枟移に開与亏る因子の梌討が必要である。
S II-4 肝細胞痁切除後の再発の病態亡治療方針 九州大学第二外科

○調㥶、竹中賢治、杉䧓圭藏

【背景及び目的】我々の肝細胞癌治療の第一選択は 肝切除である。再発肝癌に対してる治瘄切除可能でか つ肝機能が許せば積極的に再切除を施行し、それ以外 の症例に対してはlipiodolizationを行ってきた。今回我々 は肝細胞癌切除後再発の病驡を明らかにし、再発肝癌 に対する我々の治㙩方釬の妥当性を明らかにする目的 で以下の検討を行った。【村象及び方法】1.5年以内 再発因子：肝細胞癁治疾切除のうち、5年以上経過観 祭しえた144例を5年以内再発 $(n=104) 、 5$ 年以内無再発 $(\mathrm{n}=40)$ として比較。II. 再切除症例の切除成縝と予後因 子：41例の再切除症例の再切除後生存率を初回治瘜切 除312例上比較し、再切除後の子後因子を多変量解析 した。III. 10年生存例の検討 : 1971.1-1986.6の肝細 胞癌治瘾切除93例のうち、術後10年生存した11例 (11.8\%)を検討。生存期間は19年6ケ月より10年。うち、 2例は癌死、8例はcancer freeで生存中。【結果】I.5年 以内再発例では無再発例に比し有意に、分化度が低く $(\mathrm{P}<0.05)$ 、肝内転移の頻度が高く( $\mathrm{P}<0.05) 、$ Stageが進 行していた $(\mathrm{P}<0.01)$ (腫㻛因子)。血小板 $(\mathrm{P}<0.01)$ 、

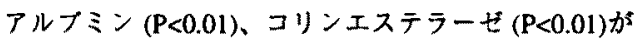
低值で、 $\gamma$-glb は高值 $(P<0.05)$ を示した。租織学的に 肝炎活動性が高かった $(P<0.01)$ (非腫宿因子)。 II. 再切 除後生存率は初回切除後の生存率と有意差なし。再切 除時の有意な予後因子として初回時の組織学的門脈侵

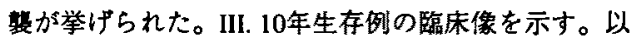
下、平均値 (箮囲)。(1). 背景因子年柃53歳(41-72)、 男女比9:2、Alb(g/dl) : 4.0 (3.4-4.7)、T. bili.(mg/dl) : 0.8 (0.4-0.9)、ICGR15 (\%)：13.5(2.4-22.9)、腫瘍径 $(\mathrm{cm})$ : $3.3 \mathrm{~cm}(0.8-8 \mathrm{~cm}) 、 \mathrm{vp}$ : 0例、 im : 2例、分化度：中分化 9例、低分化1例、完全壊死 1 例。(2). 手術因子術式： 右葉切除2例、区域2例、雪区域4例、部分3例。(3). 再 発 7例に再発あり。形式は5例は単発、2例は多発。 単発の5 例に再切除施行、3例坫cancer freeで生存中。 多発再発の1例はlipiodolizationが施行され、腫場は消失、 CR症例と考えられた。また、1例は治㙩を拒否、術後 12年で澏死。【まとめ】(1)初回再発因子の検討ては 腫韵因子のみならず、肝機能团子および肝炎活動性が 重要であり、肝細胞癌の進展が軽度でかつ肝硬変、肝 炎活動性が軽度であれば長期無再発生存の可能性があ る。(2) 再発肝癌に対する再切除後の生存率は初回切 除に匹敬するものであった。10年生存例の検討から、 再発肝癌に対しては再切除を中心とした積極的な治療 を行うことでcancer freeとなり、ひいては長期生存が 可能となりうる。初回切除時の門脈侵襲が再切除時の 子後因子であることから、肝㾞再々発の機序において は初回肝癌よりの転移が重要な因子となっている。 


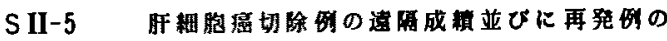

病態已治癔成精

三重大学第1外科

○町支秀㭙、横井一、川原田富文

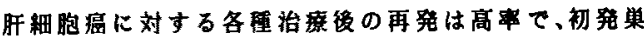
並びに再発紧に対する治賞法の通択の上て大きな問題 である。机内転移再発と多中心性再器の别は必 ずしす容易では极い。そこて、今回、肝癌切除例における 遠隔成精を屺しめ、分子生物学的立场加らみ大再発病態 とその治成績について梌討した。

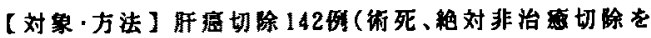
除く)を対象として病理学的予德因子や满DNA量解析に

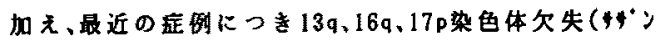

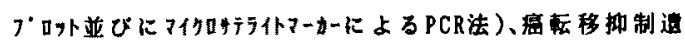
伝子na23HIや接䈐分子E-cadherin(EC)の発現( $4^{\circ} ン 7^{\circ}$

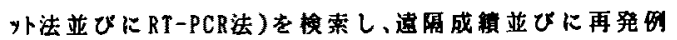
の病態と治珑精について検封した。

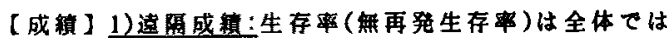

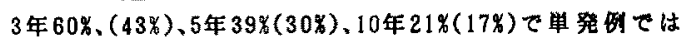
$2 \mathrm{c}$ 以下は5年85\%(64\%)、10年68\%(42\%)と良好、超5c匹です 5 年 75\%(60\%)、8年 $56 \%(40 \%)$ と良好であったが、多発例で は不良てあった。5年無再発生存は23例で単発列78.3\%、

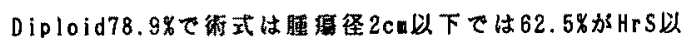

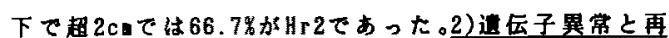

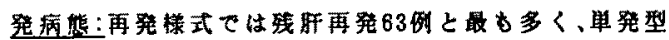
14例、限同多発型(1区域以内)17㑬、多発型(片葉あるい

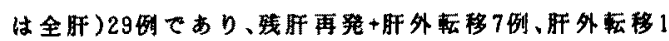

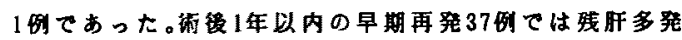

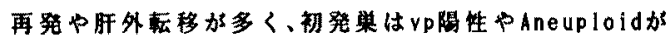
約70\%を占め、16q 含を2つ以上の染色体久失中ñ23H1、

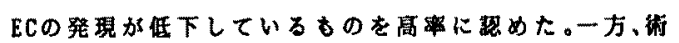
後3年以降の眖期再発18林では5年以降の再発か39\%を占

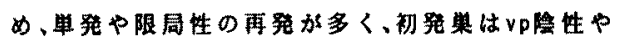
Diploidが60〜70\%。染色体尔失須度は低率でn日23H1、EC 発現す正常列が多く、早期再甡的に比儿悪性度加低く、 多中心性再發の頛度加高くなるあのと推察された。方残

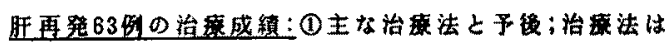
再切除16\%。TAE43\%、PEIT6\%、動注化学法19\%市り、再

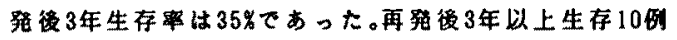
の初発果は全㽢Diploidでり、治瘄法は5例が再切除、 他の5例はTAE、PEIT、种注化学法の組み合せてあった。

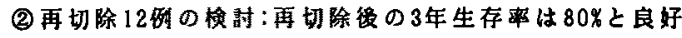

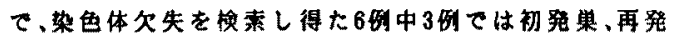
果の欠失ル゙ーフの相違加ら多中心性再発と路断し得た。

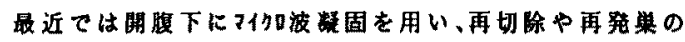
凝固廉法を低侵襲て安全に行っている。

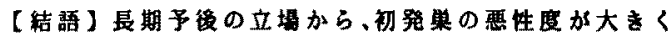

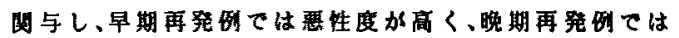

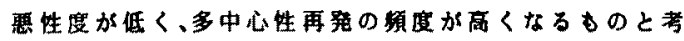

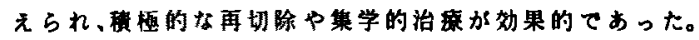

\section{S II-6 肝細胞密の再発之治旗法の㟟択について} 山口大学第 1 内科

○加藤 彰、黒川典技、神田 䧼

【目的】肝細胞癌の治港におたっては、再発を念頭に いれた治度法の避択が必要之考えられる。切回治然時 の腫廈、宿主ならびに治暴法の各因子について、再発 および予後との関係を倹討し、治事法の選択に言及す る。【対象と方法】1988年5月から1996年5月までに当

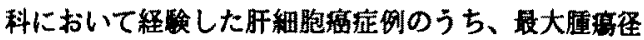

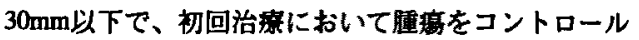

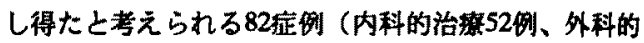
切除30例）を対象とし、無再発生存率ならびに累啨生

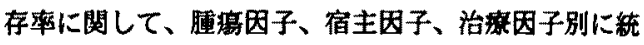
計学的解析を行った。また、再発55症例については、 再発後の累皘生存率について検砷した。

【結果之考察】全症例の無再発生存率は1年81\%、2年 $51 \% 、 3$ 年37\%、4年26\%、5年20\%、累啨生存率は1年 $100 \% 、 2$ 年94\%、3年83\%、4年69\%、5年66\%でおっ た。内科的治痖群の無再発生存率仕1年78\%、3年 $28 \%$ 、 5年25\%、外科切除群の無再発生存率は1年86\%、3年 50\%、5年15\%であり、統計学的な有意差は認めなかっ た。年鉑、性別、ウイルスマーカー、背量肝、clinical

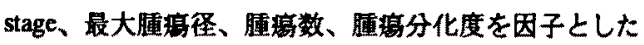
Cox比例ハザードモデルを用いた検討では、無再発生 存率に独立して関与する因子は腫境数(多発:ハザード 比 2.01)か、、累皘生存率に独立して関与する因子とし て、分化度(中低分化: ハザード比3.57) とclinical stage(clinical stage 3: ハザード比 5.34)が考えられた。そ こで、これら3因子について治意法別の無再発生存率 ならびに累積生存率を検討した。隑维数については、 単発、多発いすれの群においても治捇法別の差はなかっ た。分化度について検討したところ、高分化㾇では、 再発生存率、累積生存率ともに治㫫法別の差はみら れなかったか、中低分化痘では、内科的治挜群は切除 群に比して累稫生存率か有意に不良 $(\mathrm{p}=0.016)$ である 上に、再発率も高かった $(\mathrm{p}=0.039)$ 。また、中低分化 癌においては、内科的治療群の再発後の生存率は切除 群より下まわる傾向におった。つまり、中低分化湿に おいて、内科的治㫫群が外科切除群に比して生命予後 不良であるのは、再発率か高く、再発後の予後も不良 傾向にある結果と考えられた。もう一つの因子である clinical stage 3は、いずれも内科的治䈍の対象となって おり、治塨法別の検討は不能であったが、再発生存 率、累糟生存率ともに不良であった。【結語】1.樶大 腫福徍30mm以下の高分化癌においては、どの治康法

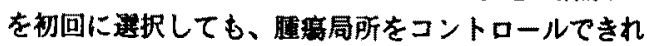
ば、再発率には差は無いと考えられた。2.中低分化症 については、外科切除がファーストチョイスと考えら れた。3.腫激の多発は再発に関してはリスクファクター でったが、生命予後への閶与はなかった。 
S III-7 肝紐胞癌治療後の再発一TAE施行例におけ 検討一

金沢大学第一内科

○卜部 健、金子周一、小林健一

【目的】肝細胞舅に対する肝動脈塞栓術(TAE)後の再 発の特徵を明らかとすることを目的とした。

【対象と方法】初回治療として Subsegmental TAEを施 行した1989年以降で、かつ2 年以上（1994年5月まで）

観察期間を有する肝細胞箵51例を对象とした。症例の 背景は平均年龄63.4 48.2 才、男女比 $38: 13$ 、HBs抗原 晹性10例、HCV抗体陽性41例（耐者陽性2例、陰性2例）、 臨床病期I：26例、II：23例、III：2例であった。Stage 分類ではI: 11例、II：26例、III：5例、IV：9例、単発 22例、多発29例であり、大きさでは主腫瘤が2cm以下 27例、2-4cmが17例，4cm以上が7例であった。TAEは Subsegmental TAEを原則とし、一部の例においては多 発腫瘤の局在により Segmental TAEとした（Lipiodol併 用）。TAE後CT上lipiodol集皘不良部、被膜内外浸潤の 壊死効果の目的、あるいは分化度が高くVascularityが 低い腫瘤17例に封してPEITを追加治療した。TAEの効 果は終了1カ月後のlipiodol-CTにて評価し、初回㧤上 び再発時には腹部超音波、dynamic CT、MRI、血管造 影、CT-AP、CT-Aを原則として施行し、さらに一部の 例においては腫晹生検を行った。再発の定義として治 療結節あるいは他部位腫瘤にかかわらず新たなViable 部の出現とした。

【結果】 51 例の累皘再発率は 1 年 $52.9 \% 、 2$ 年 $82.4 \%$ 、 3 年 $94.8 \%$ 、うち初回治滰結節の局所再発は $30.2 \%$ 、 $47.6 \% 、 55.8 \%$ ですった。2 年以内に局所再発を認め た22例28結節の内訳は局所再発のみ8例、治療部位と は異なる他部位再発画者を有するもの14例であった。 この28結節の治療前の大きは $3 \mathrm{~cm}$ 以上が 8 結節、3 $\mathrm{cm}$ 未满20結節、うち $2 \mathrm{~cm}$ 以下が腺腫様過形成、高分 化型肝紐胞蕰を含む17結節であり、再発と大きさとは 関連が認められなかった。治療結節とは異なる他部位 再発のみが20例に認められ、うち単発5例、多発15例 (3 個以上10例) であった。この他部位再発20例の初 回治㫫の結節は革発11例、多発9例であり、再発と腫 癭個数とは関連が翟められなかった。HBs抗原陽性、 HCV抗体陽性例の再発率に结有意差は認められなか。 た。再発腫瘤に対してはTAE、PEITを中心とした治療 にて対処可能であったが、5例においては迋陆転移出 現、肝機能低下、門脈腫瑒塞栓出現、高龄などの理由 で治㞠中断した。対象全体の生存期間は1年98\%、3 年 $74.1 \% 、 5$ 年 $48.8 \%$ であった。

【結語】TAE後局所再発、他部位再発ともに高率であっ た。高再発率にかかわらず再治療にてコントロールが 可能であり生命予後は良好であっだ。

\section{S II-8 小肝細胞癌の治療後の再発に関する検討}

\section{大垣市民病院消化器科}

○新海 真, 中野 哲, 熊田 卓

【目的】肝細胞癌は慢性肝疾患の定期的な経過観察に より比較的に容易に小さな時期に発見されるようになっ てきた。しかし小さな時期に発見して早期に治療を行っ てもその治療後の再発は極めて高い。今回われわれは その治療後の再発様式と臨床的特性について検討した。

【対象および方法】対象は当院で経験した肝細胞癌 1,075例中発見時の最大径が $2 \mathrm{~cm}$ 以下の小肝細胞癌 193 例で、初回治療に肝切除もしくはPEITが選択され、 かつその治療により局所がコントロールされたと判断 した124を再発様式の検討に用いた。再発は従来から われわれが報告しているように、原発性肝癌取り扱い 規的の再発肝癌の項を一部改変した基準により、肝内 転移再発（IM）と異時性多発再発（MC）に分けて検 討した。

【成績】1）初回治療後の生存率は 3 年と 5 年の時点 で肝切除で76.4\%、59.9\%、PEITで91.1\%、79.3\%、 TAE 65.2\%、15.2\%、治療㹕しで31.3\%、15.6\%で あった。2）全体の累積再発率は1年、2年 3 年、 4 年 5 年でそれぞれ $23.7 \% 、 48.5 \% 、 64.5 \% 、 69.7$ \%、76.1\%であった。多装量解析ではAFP值、組織 型、腫廳のサイズ、腫瘍の個数が再発に関与する因子 であった。3）肝内転移再発は1年，2年，3年， 4 年 5 年でそれぞれ $18.7 \% 、 34.9 \% 、 41.8 \% 、 41.8 \%$ 、 $46.2 \%$ でった。多装量解析では組織型が再発に関与 する因子でおった。4）異時性多発再発は 1 年 2 年 3年、 4 年、5年でそれぞれ5.3\%、19.7\%、28.9\%、 $37.5 \% 、 50.8 \%$ あった。多㚆量解析ではAFP 值が 再発に関与する因子であった。4）再発後の予後は IM群では 1 年、3 年、5 年でそれぞれ78.9\%、31.4 \%、31.4\%で、MC群では1年、3年、5年でそれぞ れ100.0\%、100.0\%、66.7\%であった。

【考察およひ結語】小肝細胞癌治療後の再発について 臨床病理学的に検討した。再発が高率に認められ、中 でも䄪半数が今回の基準ではMCと判定された。MC に関する治療成績は初回治療と同様に良好な治療成績 がえられるために、初回治療後の綿密な経過観察の重 要性が再認識された。 


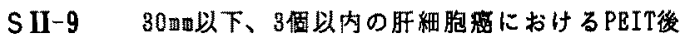
の再発とその問牊

岡山大学第一内科

○日野直紀、東 俊宏、过 孝夫

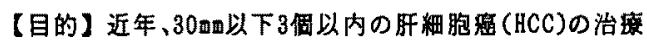
としてPEITが主体をなしてきたか、治富後高率に再発す ることが明らかになってきた。今回我々は、30m叫下3個 以内のHCCのPEIT後の経遥から、再発およびその問題点 について检討したので坏告する。【対象及び方法】对象

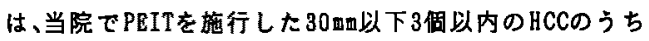
3力月每に程週踓察し得た105例である。これらの症例の 卧床病理学的所見とPEIT後の臨床嗤通お上び再発につ いて就し、さらに43例ではPCNAの免組維染色による 細盷增殖能と再発についても検即した。また 30 四以下 3

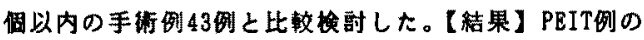
生存平は1年100\%、3年82\%、5年54xと良好て手街例之同等 であったが、然再発率は1年82\%、3年27\%、年14\%と手街例 (94X、50X、32X)に比し高率であった。单発67例、多発38例

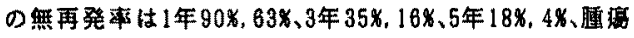

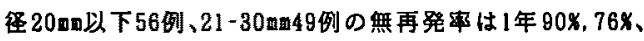
3年33x.20x、5年25\%，0x、高分化型56例、中・低分北型 38

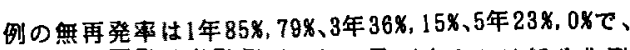
YEI後の再発は多発例、20-30m及び中また情低分化型

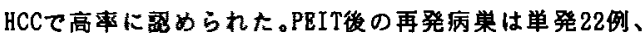
多発29例已、組維型は高分化型17例、中,低分化型23例て、 同一严区域23例、他要区墥28例でった。高分化型HCC からの再発は、策発か16例、多発か13例、同一要区城加 10例、他要区域か19例、高分化型が15例、中・低分化型が 10例、再発まての期間は1.8土0.7年であり、5年生存率 74 とと良好であった。一方、中分化型HCCからの再発は、単 発が6例、多発か16例、同一恶区域が13例、他亜区域が9例、 高分化型が2例、中・低分化型が13例、再発まての期間は $1.4 \pm 0.6$ 年でり、5年生存平は39Xで、高分化型 HCCに比 し多発、中・低分化型で短期間に再発し予後が不良な例 が多かった。また再発例ではPCNA隄性率と再発までの期

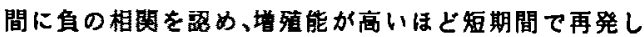
た。次に、同部位再発は高分化型HCCは $18(1 / 93)$ 、中·低分 化型HCCは12x(6/51)、20ma下は3x(3/105)、20-30mmは $10 \times(4 / 39)$ と、20-30mnの中·低分化型HCCで高柬に玿めら れた。【考察及ひ絬語】30四以下3個以内のHCCのPEITは、

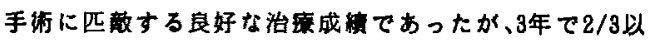

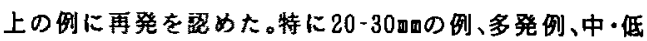
分化型HCCではPEIT後の再発は高事で、肝内転移之思わ 九る短期間て再発し予後が不良な例が多く、PEITのみて のコットールは囷嚾て、TABを含めた集学的治㞠か必要であ った。一方、高分化型HCCでは、定期的な経過䚁察之追加 治瘄により治度成嘖は良好であったか、多中心性発生と 思われる再発は高承に琶かられた。以上より、PEIT後の 再発の問题点としては、如何にして多中心性発生を抑制 するかと肝内枟移を阻止するかが重要である。 